\title{
Comparison of the bacterial community composition in the granular and the suspended phase of sequencing batch reactors
}

\author{
Enikö Szabó ${ }^{*}{ }^{*}$, Raquel Liébana ${ }^{1}$, Malte Hermansson², Oskar Modin ${ }^{1}$, Frank Persson ${ }^{1}$ and Britt-Marie Wilén ${ }^{1}$
}

\begin{abstract}
Granulation of activated sludge is an increasingly important area within the field of wastewater treatment. Granulation is usually achieved by high hydraulic selection pressure, which results in the wash-out of slow settling particles. The effect of the harsh wash-out conditions on the granular sludge ecosystem is not yet fully understood, but different bacterial groups may be affected to varying degrees. In this study, we used high-throughput amplicon sequencing to follow the community composition in granular sludge reactors for 12 weeks, both in the granular phase and the suspended phase (effluent). The microbiome of the washed out biomass was similar but not identical to the microbiome of the granular biomass. Certain taxa (e.g. Flavobacterium spp. and Bdellovibrio spp.) had significantly $(p<0.05)$ higher relative abundance in the granules compared to the effluent. Fluorescence in situ hybridization images indicated that these taxa were mainly located in the interior of granules and therefore protected from erosion. Other taxa (e.g. Meganema sp. and Zooglea sp.) had significantly lower relative abundance in the granules compared to the effluent, and appeared to be mainly located on the surface of granules and therefore subject to erosion. Despite being washed out, these taxa were among the most abundant members of the granular sludge communities and were likely growing fast in the reactors. The ratio between relative abundance in the granular biomass and in the effluent did not predict temporal variation of the taxa in the reactors, but it did appear to predict the spatial location of the taxa in the granules.
\end{abstract}

Keywords: Aerobic granular sludge, Microbial community composition, Wash-out dynamics, Temporal variation, Spatial distribution, Sequencing batch reactors

\section{Introduction}

Wastewater treatment by aerobic granular sludge is a low-footprint technology that allows effective pollutant removal even at high loading rates (Beun et al. 1999; de Bruin et al. 2004). During granulation, bacterial cells are self-immobilized in an EPS (extracellular polymeric substances) matrix, resulting in a dense, compact structure with an anaerobic/anoxic core and an aerobic outer layer (Beun et al. 2001; de Kreuk et al. 2005).

Granulation is usually achieved by high hydraulic selection pressure, i.e. a sequencing batch reactor (SBR)

\footnotetext{
*Correspondence: eniko.szabo@chalmers.se

${ }^{1}$ Division of Water Environment Technology, Department

of Architecture and Civil Engineering, Chalmers University of Technology,

41296 Gothenburg, Sweden

Full list of author information is available at the end of the article
}

is operated either with short settling time (variable volume operation mode) or with high upflow velocity (constant volume operation/fill-draw mode), both resulting in the wash-out of slow settling particles. Low effluent quality due to high suspended solids (SS) concentration has frequently been reported both in laboratory-scale and pilot-scale applications, fed with synthetic and/or real wastewater (Inizan et al. 2005; Yilmaz et al. 2008; Morales et al. 2013; Rocktäschel et al. 2015; Derlon et al. 2016). Strategies to decrease the effluent SS concentration include lower upflow velocity combined with selective sludge removal (Pronk et al. 2015; Derlon et al. 2016) or longer settling time and lower degree of granulation (Rocktäschel et al. 2015).

The ecological implications of the strong wash-out conditions on the microbial community are not yet fully 
understood, despite being one of the strongest selective forces applied in SBRs for aerobic granulation. It has been shown that the wash-out rate of different bacterial groups can be different, depending on their spatial distribution within the granule (Winkler et al. 2012). Bacterial populations growing on the surface of the granules may be eroded and washed out in higher numbers than bacteria growing deeper in the granule. Thus, bacterial groups situated in the exterior layer of the granules are likely to contribute more to the suspended solids content in the effluent than bacteria situated in the interior layer. However, if a granule breaks up, exterior and interior bacterial populations will be washed out equally, presuming that the particles are not too dense. The density of the broken granule particle depends on the type(s) of bacteria it is comprised of (Gonzalez-Gil and Holliger 2014), and on the predominant granulation mechanisms-self-aggregation of floccular biomass, self-aggregation of small granules (microcolony aggregation), microcolony outgrowth, or attachment of floccular biomass to granular biomass (Barr et al. 2010; Verawaty et al. 2012; Zhou et al. 2014). Depending on process conditions and the bacteria dominating the microbial community, different granulation mechanisms were reported to prevail (Weissbrodt et al. 2013).

In this study, we followed the community composition in granular sludge reactors at different operational conditions for 12 weeks, both in the granular phase and the suspended phase (effluent). This work is, to our knowledge, the first report about the microbial community composition in the effluent of granular sludge reactors. We assessed how the spatial distribution of certain taxa affected its wash-out, and compared the bacterial community in the granular and suspended phases to gain better understanding of the successional patterns in granular sludge reactors.

\section{Materials and methods \\ Reactor setup and medium}

The experiments were carried out in three columnshaped SBRs, each with a working volume of $3 \mathrm{~L}$, a diameter of $6 \mathrm{~cm}$, and a total height of $132 \mathrm{~cm}$. The influent was pumped in at the bottom of the reactor. The air was introduced also at the bottom through a diffusor stone (pore size $1 \mu \mathrm{m}$ ) with a superficial upflow air velocity of $1.5 \mathrm{~cm} / \mathrm{s}$. The effluent was withdrawn at $63 \mathrm{~cm}$ from the bottom, resulting in a volume exchange ratio of $43 \%$. The reactors were run with $4 \mathrm{~h}$ cycles, one cycle consisted of 5 min filling, 55 min anaerobic phase, $143-171$ min aerobic phase, 2-30 min settling, 5 min withdrawal and $2 \mathrm{~min}$ idle. The settling time was gradually decreased (Additional file 1: Figure S1) to allow a better retention of nitrifying organisms (Szabó et al. 2016), and the aerobic phase was concomitantly increased to permit an even, $4 \mathrm{~h}$ cycle length. The reactors were seeded from a full-scale wastewater treatment plant (Gryaab, Gothenburg) with aerobic/anoxic activated sludge. The reactors were fed with a $50-50 \%$ mixture of synthetic and real wastewater (6-times diluted reject water from the dewatering of digested sludge). The synthetic wastewater consisted of a concentrated acetate solution and an inorganic salt solution, pumped from separate bottles. The final composition of the synthetic wastewater is given in Additional file 1: Table S1. Reject water was used as the source of ammonium. The total organic and nitrogen loading rates as well as the influent COD and $\mathrm{N}$ concentrations are shown in Table 1. Three different organic loading rates were used, which allowed the comparison of the effect of wash-out at different food-to-microorganism ratios. The $\mathrm{pH}$ and the temperature of the reactors were not regulated, and varied in the range of $7.0-9.0$ and $19-21{ }^{\circ} \mathrm{C}$, respectively.

\section{Sampling and chemical analysis}

Effluent parameters were measured three times a week with a Shimadzu TOC analyzer (total organic carbon, total nitrogen) and a Dionex ICS-900 ion chromatograph $\left(\mathrm{NH}_{4}-\mathrm{N}, \mathrm{NO}_{2}-\mathrm{N}, \mathrm{NO}_{3}-\mathrm{N}\right)$. Total suspended solids and volatile suspended solids in the effluent were measured according to standard methods (APHA 1995). Biomass samples of $100 \mathrm{~mL}$ were withdrawn from the reactors three times per week.

\section{Process performance}

The process performance reached steady state after approximately 6 weeks of operation. The COD removal was stable from the first day of operation, above 95, 90

Table 1 Operational parameters and process performance

\begin{tabular}{|c|c|c|c|c|}
\hline Parameter & Unit & R1 & R2 & R3 \\
\hline t & $\mathrm{H}$ & 4 & 4 & 4 \\
\hline OLR & $\begin{array}{l}\mathrm{kg} C O D / \mathrm{m}^{3} / \\
\text { day }\end{array}$ & $3.71 \pm 0.04$ & $1.87 \pm 0.04$ & $0.91 \pm 0.04$ \\
\hline NLR & $\begin{array}{l}\mathrm{kg} \mathrm{NH}_{4}-\mathrm{N} / \mathrm{m}^{3} / \\
\text { day }\end{array}$ & $0.22 \pm 0.02$ & $0.22 \pm 0.02$ & $0.22 \pm 0.02$ \\
\hline COD:N ratio & - & 100:6 & $100: 12$ & $100: 24$ \\
\hline Influent COD & $\mathrm{mg} / \mathrm{L}$ & $1416 \pm 14$ & $712 \pm 14$ & $346 \pm 14$ \\
\hline Influent $\mathrm{NH}_{4}-\mathrm{N}$ & $\mathrm{mg} / \mathrm{L}$ & $85 \pm 6$ & $85 \pm 6$ & $85 \pm 6$ \\
\hline $\mathrm{E}_{\mathrm{COD}}$ & $\%$ & $98.3 \pm 1.1$ & $96.0 \pm 1.4$ & $86.3 \pm 0.6$ \\
\hline $\mathrm{E}_{\mathrm{NH} 4}$ & $\%$ & 100 & 100 & 100 \\
\hline $\mathrm{E}_{\mathrm{TN}}$ & $\%$ & $65.5 \pm 7.2$ & $38.1 \pm 16.4$ & $0.4 \pm 19.0$ \\
\hline Effluent SS & $\mathrm{mg} / \mathrm{L}$ & $301 \pm 98$ & $133 \pm 28$ & $74 \pm 13$ \\
\hline
\end{tabular}

Cycle length (t); organic and nitrogen loading rate (OLR, NLR); COD:N ratio; influent $\mathrm{COD}$ and $\mathrm{NH}_{4}-\mathrm{N}$ concentration; removal efficiency (E) of $\mathrm{COD}, \mathrm{NH}_{4}$ and TN during the last 4 weeks; average effluent suspended solids concentration (SS) 
and $80 \%$ in R1, R2 and R3 respectively. The suspended solids concentration in the effluent fluctuated between 0.04 and $0.5 \mathrm{~g} / \mathrm{L}$ (Additional file 1: Figure S2). Complete ammonium removal was achieved after 3, 4 and 6 weeks in R1, R2 and R3 respectively (Additional file 1: Figure S3). The nitrite concentration peaked after 3-4 weeks of operation, and all nitrite was fully converted to nitrate after 6-7 weeks of operation. The total nitrogen removal also reached steady state after 6-7 weeks. Based on the process performance, weeks $1-6$ are defined as the startup period, and weeks 7-12 are defined as the steady state period. The average removal efficiency of organic material, ammonium and total nitrogen during the last 4 weeks are shown in Table 1.

\section{DNA extraction, PCR, sequencing and data analysis}

Biomass for DNA extraction was collected three times per week, both from the withdrawn reactor samples (granular phase) and from the effluent (suspended phase), at the end of the aerated phase. DNA was extracted using the FastDNA Spin Kit for Soil (MP Biomedicals) following the manufacturer's protocol, from $46 \pm 12 \mathrm{mg}$ of biomass (wet weight) per sample. 16S rRNA genes were amplified in duplicates, using the AccuPrime Pfx SuperMix (Life Technologies), $20 \mathrm{ng}$ template, and $1 \mu \mathrm{M}$ forward (515F) and $1 \mu \mathrm{M}$ reverse (806R) primers, dual-indexed according to Kozich et al. (2013). The PCR reaction, carried out in a Biometra T3000 Thermocyler, started with 5 min enzyme activation at $95{ }^{\circ} \mathrm{C}$, followed by 30 cycles of denaturation $\left(95^{\circ} \mathrm{C}, 20 \mathrm{~s}\right)$, annealing $\left(50^{\circ} \mathrm{C}, 15 \mathrm{~s}\right)$ and elongation $\left(68^{\circ} \mathrm{C}, 60 \mathrm{~s}\right)$, and finished by a $10 \mathrm{~min}$ final elongation at $68^{\circ} \mathrm{C}$. The duplicate PCR products were pooled, the DNA concentrations were normalized and the samples were purified using the Agencourt AMPure system (Beckman Coulter). The PCR products were multiplexed and diluted with Tris- $\mathrm{Cl}(\mathrm{pH} 8.5,0.1 \%$ Tween20) for a final concentration of $0.6 \mathrm{ng} / \mu \mathrm{L}$, as measured by Qubit 2.0 (Life Technologies). The expected concentration and size of the pooled PCR product was confirmed by TapeStation 2200 (Agilent Technologies). PhiX control library was spiked in at $7.5 \%$. Sequencing was performed on an Illumina MiSeq using the MiSeq Reagent Kit v2. In total, 78 samples were analyzed in this study, 26 from each reactor (13 from the granular phase and 13 from the effluent). The sequences were processed and classified, using the MiDAS taxonomy, as published in Albertsen et al. (2015), prior to statistical analyses in R ( $R$ Core Team 2016). Retention ratios were calculated by dividing the relative read abundance in the reactor with the relative read abundance in the effluent. Margalef's species richness and Pielou's evenness were calculated using the package vegan (Oksanen et al. 2015), non-metric multi-dimensional scaling (NMDS) ordination plots and heatmaps were created using the package ampvis (Albertsen et al. 2015), and basic R functions were used to create the Tukey boxplots, perform one-sample Wilcoxon signed-rank tests and calculate Pearson correlation coefficients $(\mathrm{r})$. The sequences were deposited as an NCBI BioProject (BioProject ID: PRJNA384775).

\section{Fluorescence in situ hybridization (FISH)}

FISH was performed on intact granules harvested from the reactors at day 55. Granules were fixed in $4 \%$ paraformaldehyde for $8 \mathrm{~h}$ at $4{ }^{\circ} \mathrm{C}$ and washed twice with PBS. Fixed granules were stored in PBS/ethanol (50:50) at $-20{ }^{\circ} \mathrm{C}$ until use. For cryosectioning, granules were incubated overnight at $4{ }^{\circ} \mathrm{C}$ in O.C.T. Compound (VWR, Radnor, PA, USA) in individual plastic containers. Thereafter, a dry ice fume chamber was used to freeze each granule in blocks, which were stored at $-70{ }^{\circ} \mathrm{C}$ until use. Granule cryosections, $10-20 \mu \mathrm{m}$ thick, were obtained at $-20{ }^{\circ} \mathrm{C}$ using a HM550 microtome cryostat (MICROM International GmbH, Germany). The cryosections were collected on SuperFrost ${ }^{\circledR}$ Plus Gold microscope slides (Menzel $\mathrm{GmbH}$, Germany) and stored at $-20{ }^{\circ} \mathrm{C}$. Prior to $\mathrm{FISH}$, a Liquid Blocker Mini PAP Pen (Life Technologies) was used to apply a hydrophobic barrier on the glass slides framing the cryosections, which were subsequently covered with a thin layer of agarose $(1 \% \mathrm{w} / \mathrm{v})$ and dehydrated in an ethanol series (50, 80 and $96 \% \mathrm{v} / \mathrm{v})$. FISH was performed at $46{ }^{\circ} \mathrm{C}$ for $2 \mathrm{~h}$ (Manz et al. 1992) using the probes and hybridization conditions shown in Table 2. Syto 40 was used as a counterstain. The target organisms were chosen based on their retention ratios. Confocal images were acquired using a Zeiss LSM700 (Carl Zeiss, Germany) with $10 \times / 0.45$ plan-apochromat and $40 \times / 1.3$ plan-apochromat oil objectives and laser diode lines of 405, 488, 555 and $639 \mathrm{~nm}$. Large images covering the entire granules and large sections were acquired using the averaging $(n=4)$ and tiling functions of Zeiss ZEN2010 software.

\section{Results \\ Population dynamics}

The overall trend in the evolution of the bacterial communities is shown in Fig. 1. The community composition of the granular and of the suspended phase followed the same dynamics throughout the experiment in all three experimental set-ups. The average community similarity (Bray-Curtis) between contemporaneous granular and effluent samples from the same reactor is $65 \pm 2 \%$ in $\mathrm{R} 1,63 \pm 6 \%$ in R2, and $65 \pm 7 \%$ in R3. For comparison, the average similarity between the three different experimental set-ups was $26-40 \%$ by the end of the experiment. This difference is expected, due to the different OLR applied to the reactors. The effect of the different loading rates on the microbial population dynamics is discussed 
Table 2 Probes and hybridization conditions for FISH

\begin{tabular}{llll}
\hline Probe & Target organism & FA (\%) & References \\
\hline BDE525 & Genus Bdellovibrio & 35 & Mahmoud et al. (2007) \\
CFB563 & Most Flavobacteria & 20 & Weller et al. (2000) \\
Meg983 & Meganema perideroedes & 35 & Thomsen et al. (2006) \\
Meg1028 & Meganema perideroedes & 45 & Thomsen et al. (2006) \\
ZRA23a & Most members of the Zoogloea lineage & 35 & Rosselló-Mora et al. (1995) \\
ZOGLO-1416 & Zoogloea spp. & 35 & Loy et al. (2005) \\
\hline
\end{tabular}

FA formamide concentration in the hybridization buffer

in a separate publication (Szabó et al. 2017). Correlation analyses show a strong correlation between samples from the effluent and samples from the reactor content (Additional file 1: Figure S4).

\section{Retention ratios of abundant microorganisms}

Although the community composition of the effluent and the granules was similar, it was not identical. As it can be seen in Fig. 2, there are notable differences between the relative read abundances of certain dominant genera in the suspended and granular communities.

To be able to analyze the difference between effluent and granule samples more thoroughly, the ratio of the relative abundances in contemporaneous samples was calculated for the dominant genera. This approach is similar to that suggested by Winkler et al. (2012), where they use a dimensionless "species proportion ratio" to determine whether preferential wash-out of certain bacterial groups occurs in the granular sludge reactor. We calculate the "retention ratio" by dividing the relative read abundance in the granules with the relative read abundance in the effluent. Thus, a retention ratio larger than 1 indicates good retention of the taxa in the reactor.

The correlation analysis (Table 3 ) of the retention ratios and the number of days since start-up show that some taxa (e.g. Acidovorax in R2 and R3, Brevundimonas in $\mathrm{R} 1)$ were increasingly retained as the experiment progressed. Other genera became progressively more abundant in the effluent (e.g. Meganema in R1, Leptothrix in $\mathrm{R} 2$ ), although this was a less common phenomenon.

In many cases, the retention ratio did not show any significant temporal trends. However, for some genera, statistically significant differences between the start-up phase (weeks 1-6) and the steady-state operation (weeks

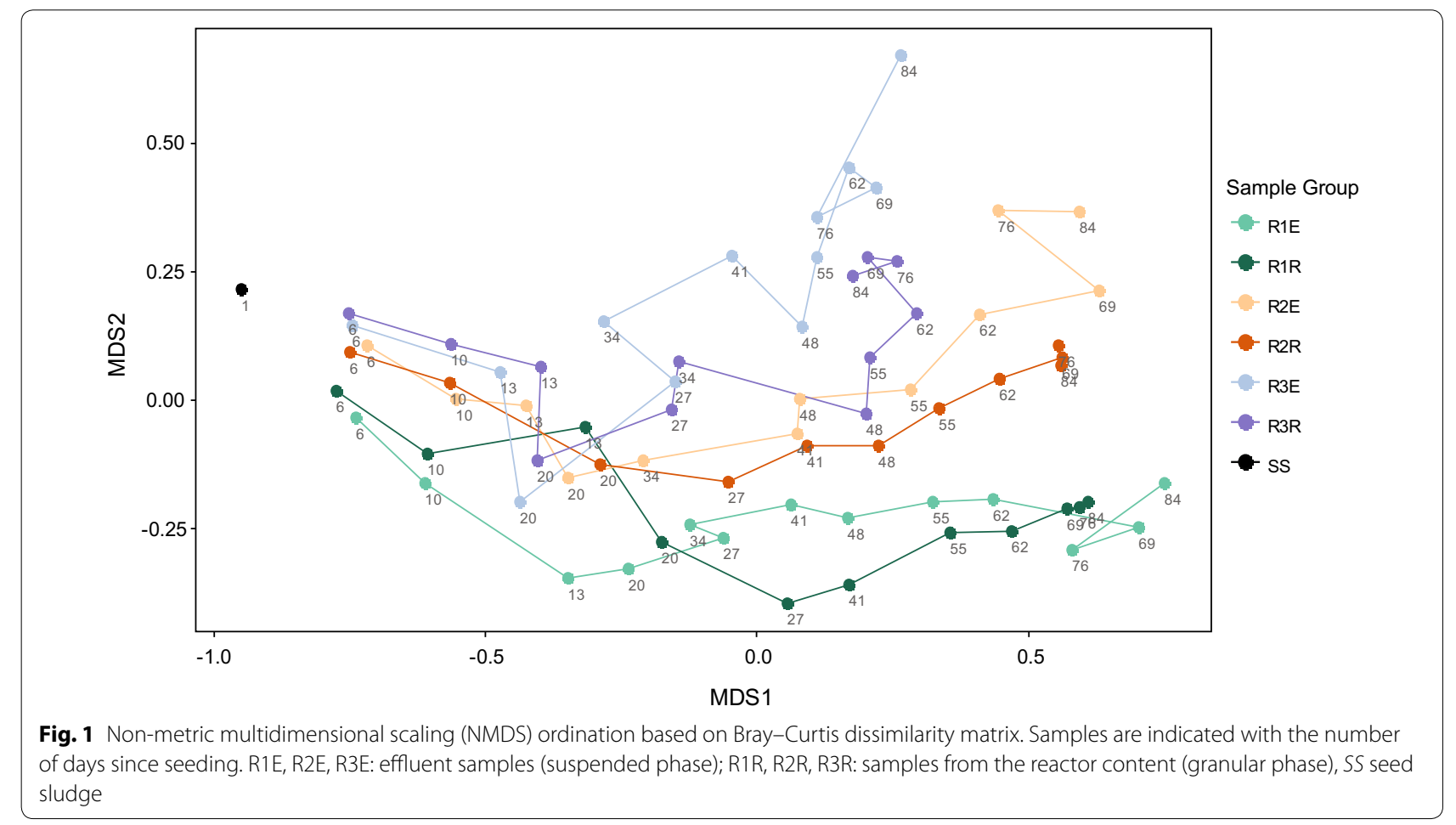




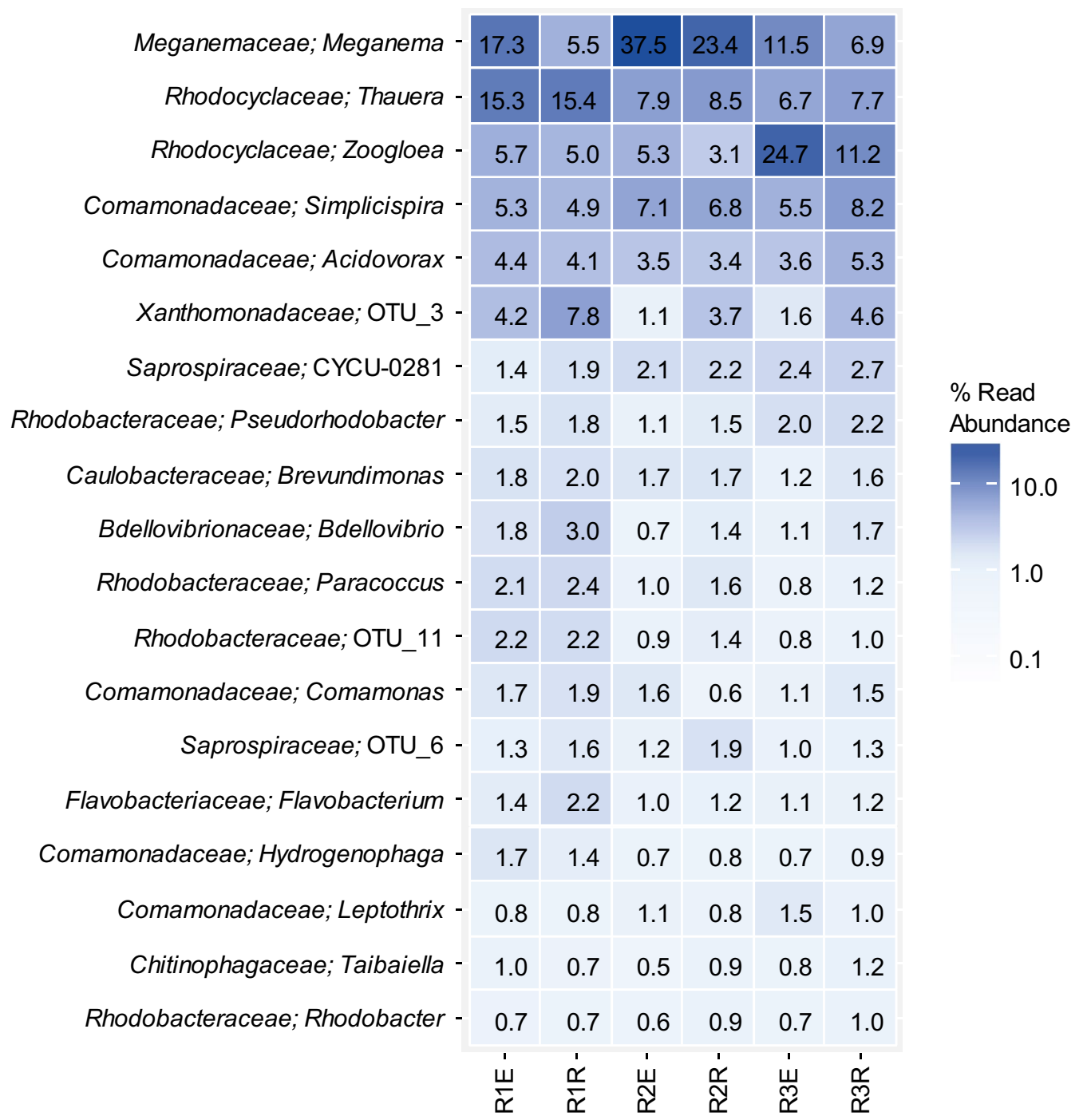

Fig. 2 Average relative read abundance $(n=13)$ of the most abundant genera common for all six sample categories. These 19 genera add up to $65 \pm 11 \%$ of the total population in the samples. R1E, R2E, R3E: effluent samples (suspended phase); R1R, R2R, R3R: samples from the reactor content (granular phase)

7-12) could be found (Fig. 3). During start-up (the first 6 weeks of operation), most genera had a retention ratio around 1, i.e. they were washed out proportionally to their relative abundance in the granular biomass (Additional file 1: Figure S5); while during steady-state operation, the retention ratio of certain genera was significantly higher (or lower) than one (Fig. 3). The average relative read abundances of the most common genera for the start-up and steady-state period are shown in Additional file 1: Figure S6.

\section{FISH on granule cryosections}

To assess the spatial localization of bacteria with high or low retention ratios, cryosectioned slices of granules were dyed with FISH probes targeting some of the most abundant genera.

Meganema and Zoogloea are genera that had retention ratios significantly lower than one during steady-state operation. Both genera were found to be growing mainly on the surface of the granules (Fig. 4). The filaments of Meganema extend outside the granule surface. Zoogloea was found exclusively within $100 \mu \mathrm{m}$ from the surface; the outgrowths resemble the finger-like structures typical for Zoogloea.

Bdellovibrio and Flavobacterium are two genera with retention ratios significantly higher than one during steady-state operation. They were found to be growing often in the deeper regions of the granule (Fig. 5). 
Table 3 Correlation analyses of retention ratios and the number of days since start-up

\begin{tabular}{|c|c|c|c|c|c|c|}
\hline & \multicolumn{2}{|l|}{ R1 } & \multicolumn{2}{|l|}{ R2 } & \multicolumn{2}{|l|}{ R3 } \\
\hline & p & $\mathbf{R}$ & $p$ & $r$ & $p$ & $r$ \\
\hline g_Acidovorax & 0.8285 & -0.0668 & $0.0099^{* *}$ & 0.6841 & $0.0065^{* *}$ & 0.7104 \\
\hline g_Bdellovibrio & 0.2792 & 0.3584 & $0.0579 \bullet$ & 0.5380 & $0.0143^{*}$ & 0.7405 \\
\hline g_Brevundimonas & $0.0084^{* *}$ & 0.6947 & 0.0953 & 0.4821 & $0.0542 \cdot$ & 0.5449 \\
\hline g_Comamonas & 0.8125 & -0.0731 & $0.0127^{*}$ & 0.6915 & 0.3800 & 0.2941 \\
\hline g_Flavobacterium & $0.0073^{* *}$ & 0.7033 & $0.0006^{* * *}$ & 0.8418 & $0.0596 \bullet$ & 0.5350 \\
\hline g_Hydrogenophaga & $0.0720 \cdot$ & 0.5145 & 0.6511 & 0.1388 & $0.0198^{*}$ & 0.6346 \\
\hline g_Leptothrix & 0.5783 & 0.1702 & $0.0376^{*}$ & -0.5803 & 0.6190 & 0.1525 \\
\hline g__Meganema & $0.0296^{*}$ & -0.6524 & 0.1573 & -0.4352 & 0.1005 & -0.4756 \\
\hline g_Paracoccus & 0.2592 & 0.3377 & 0.5587 & 0.1789 & 0.9165 & 0.0323 \\
\hline g_Pseudorhodobacter & $0.0042^{* *}$ & 0.7350 & 0.4281 & 0.2408 & 0.8144 & -0.0723 \\
\hline g_Rhodobacter & 0.1282 & 0.4443 & 0.4015 & 0.2545 & 0.8502 & 0.0612 \\
\hline g__Simplicispira & 0.5592 & 0.1787 & 0.2985 & 0.3125 & 0.1308 & 0.4417 \\
\hline g_Taibaiella & 0.5992 & -0.1610 & 0.4869 & 0.3181 & 0.1255 & 0.4471 \\
\hline g_thauera & 0.4142 & -0.2479 & $0.0008^{* * *}$ & 0.8100 & $0.0258^{*}$ & 0.6132 \\
\hline 9_Zoogloea & 0.4673 & -0.2324 & 0.9779 & -0.0090 & 0.5396 & -0.1875 \\
\hline OTU_11 & 0.4770 & -0.2167 & 0.4361 & 0.2368 & 0.3820 & -0.2778 \\
\hline OTU_6 & $0.0007^{* * *}$ & 0.8571 & $0.0105^{*}$ & 0.7612 & $0.0185^{*}$ & 0.6640 \\
\hline OTU_3 & 0.2225 & 0.3632 & 0.7140 & 0.1331 & $0.0049^{* *}$ & 0.7767 \\
\hline g_CYCU.0281 & 0.5169 & 0.1979 & $0.0103^{*}$ & 0.6818 & $0.0677^{*}$ & 0.5437 \\
\hline
\end{tabular}

Significant correlations are marked with asterisk(s). Cutoff levels: $(\cdot) p<0.1,\left({ }^{*}\right) p<0.05,\left(^{* *}\right) p<0.01,\left({ }^{* *}\right) p<0.001$. For OTU_3, OTU_6 and OTU_11, the closest matches by BLASTn (Altschul et al. 1990) are shown in Additional file 1: Table S2

\section{Discussion}

Based on the dissimilarity matrices and the correlation analyses, it appears that the community composition of the effluent is similar but not identical to the community composition of the granular sludge. By calculating the retention ratios, the similarities and differences could be examined more thoroughly. Some genera became more abundant in the effluent as the experiment progressed. Other genera, on the contrary, were increasingly retained as the flocculated biomass turned into granules.

During start-up (the first 6 weeks of operation), many genera seemed to be washed out proportionally to their relative abundance in the biomass. We assume that during start-up a large fraction of the biomass is still flocculated, and every floc has similar settleability. Thus the probability of cells being discharged with the effluent is similar for every taxa, irrespective of which floc they are attached to or where in the floc they are situated. As soon as granules start to develop, differences in settleability emerge, and depending on the spatial location and the granulation mechanisms some cells are more likely to be washed out than others.

During steady-state operation (weeks 7-12), most of the biomass is granulated and dense enough to be retained in the reactor. Nonetheless, certain genera had a retention ratio significantly lower than one (Fig. 3), i.e. they were more abundant in the effluent than in the granules. A possible explanation is that these genera were situated on the surface of the granule, and were therefore exposed to granule erosion, as suggested by Winkler et al. (2012). They found that bacterial groups situated on the surface (e.g. ammonium oxidizing bacteria) were more prone to be washed out than bacterial groups situated in the core of the granules. We found that two abundant groups of bacteria, Meganema sp. and Zoogloea sp., which had a low retention ratio in all three reactors during steady-state operation (Fig. 3), were situated mostly in the outer layer of the granules, where the biomass was loosely packed (Fig. 4) and therefore more likely to be washed out due to granule erosion. Meganema sp. is usually found in aerobic environments, therefore it is not expected to grow in the inner parts of the granules (Kragelund et al. 2005). Zoogloea sp. has been reported to produce EPS containing high amounts of water and to grow as slimy colonies, thus the high abundance of these bacteria in the outer layer might explain the lower density of this part of the granule (Thomsen et al. 2007; Nielsen et al. 2010). Moreover, the typical morphological characteristics of these genera (filamentous growth for Meganema sp. (Kragelund et al. 2005), and fingerlike structures in case of Zoogloea sp. (Rosselló-Mora et al. 1995) make them even more likely to detach when 
a

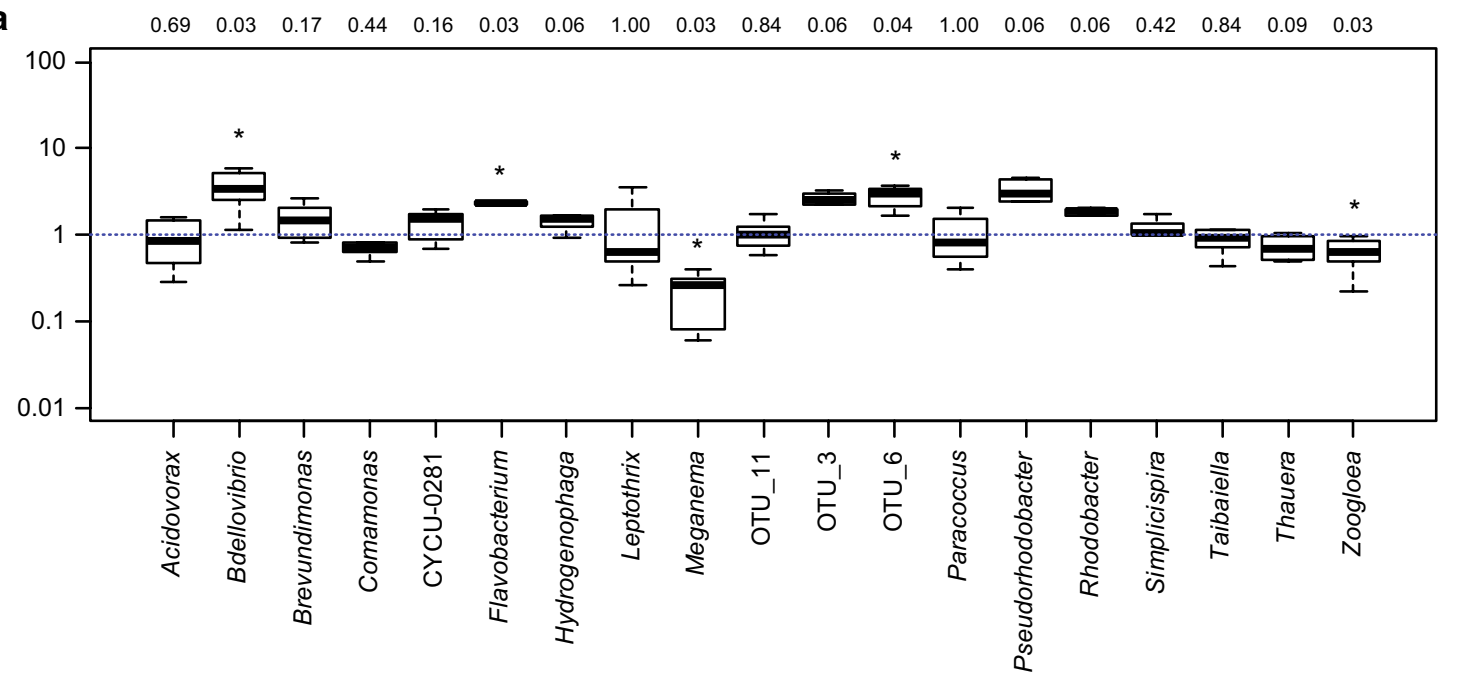

b

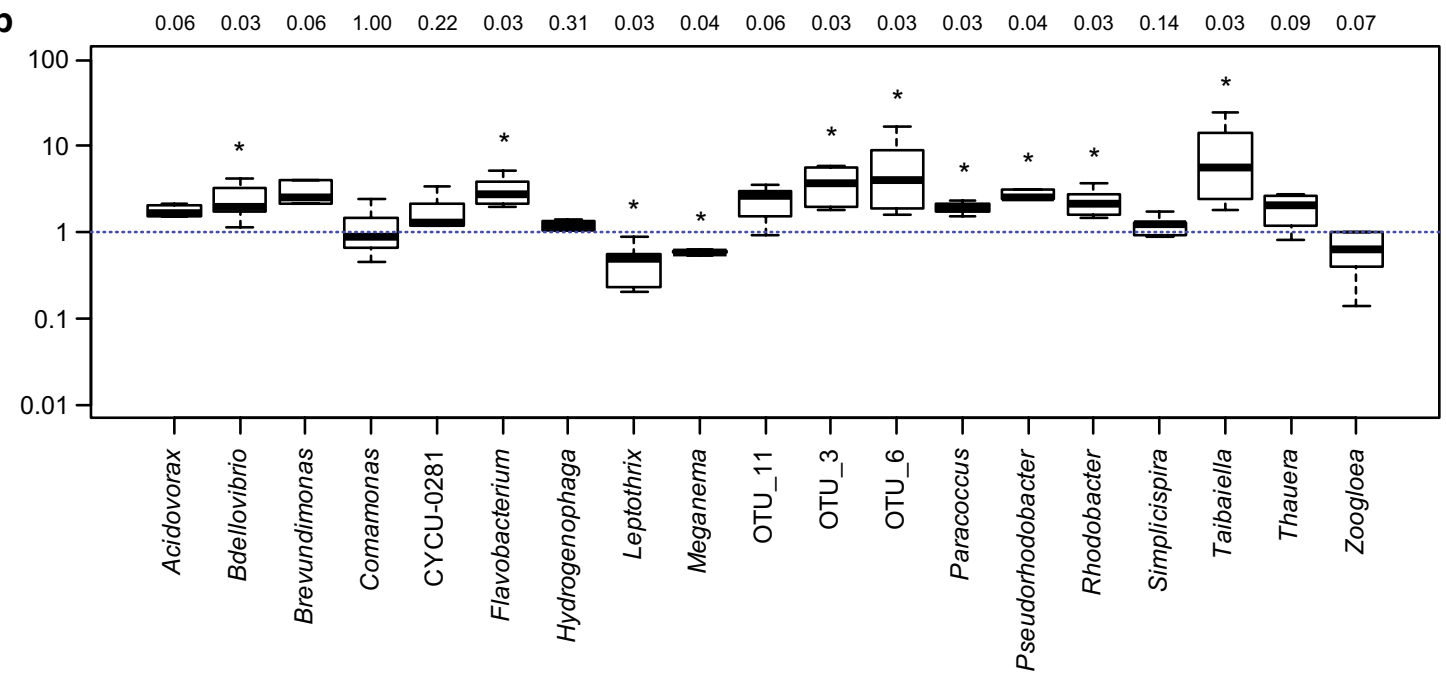

C

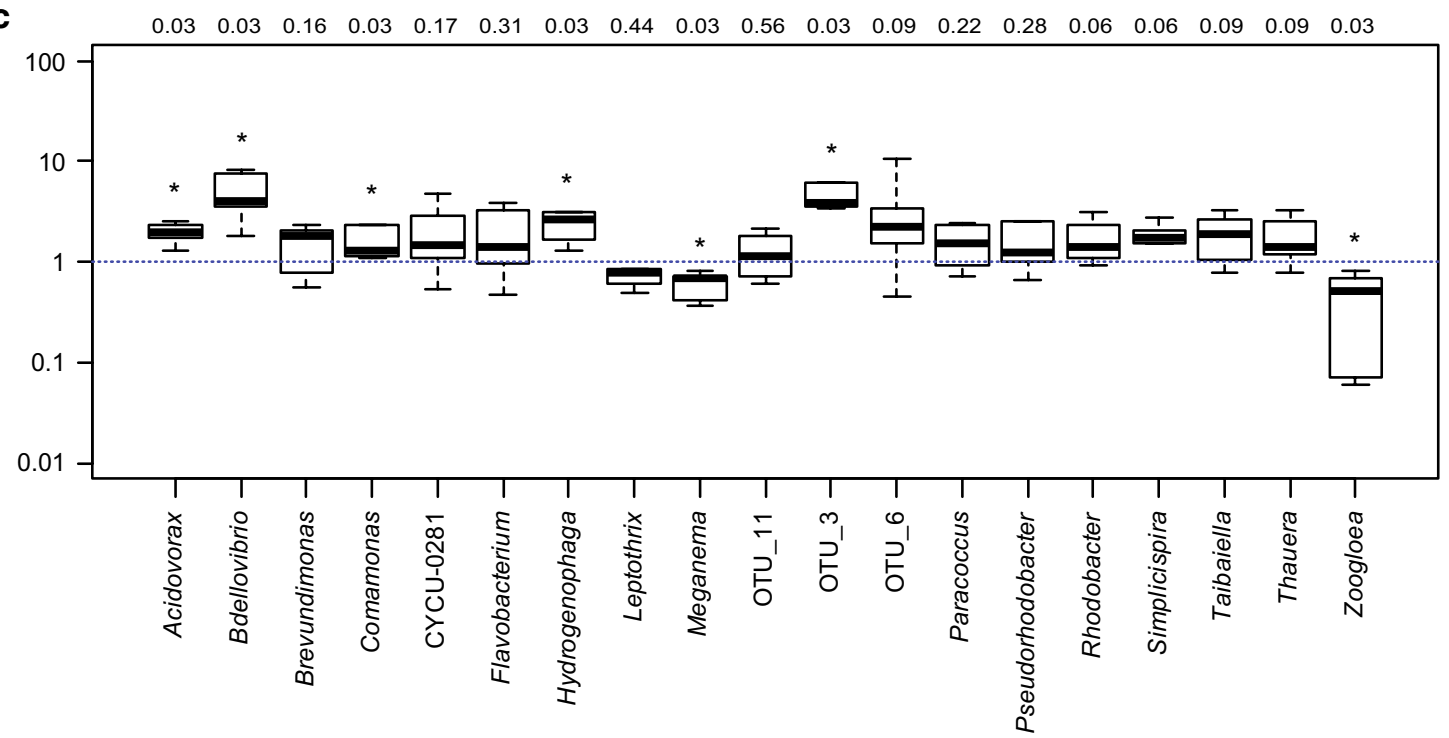

Fig. 3 Boxplots of the retention ratios during steady-state operation (weeks 7-12) in R1 (a), R2 (b) and R3 (c). Values significantly different from 1 are marked with asterisk ( $p$ values are shown above the plots) 
a

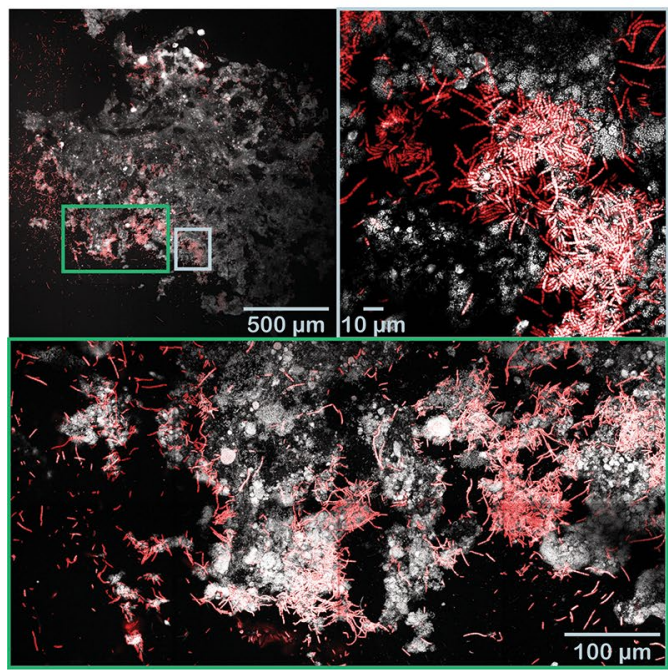

C

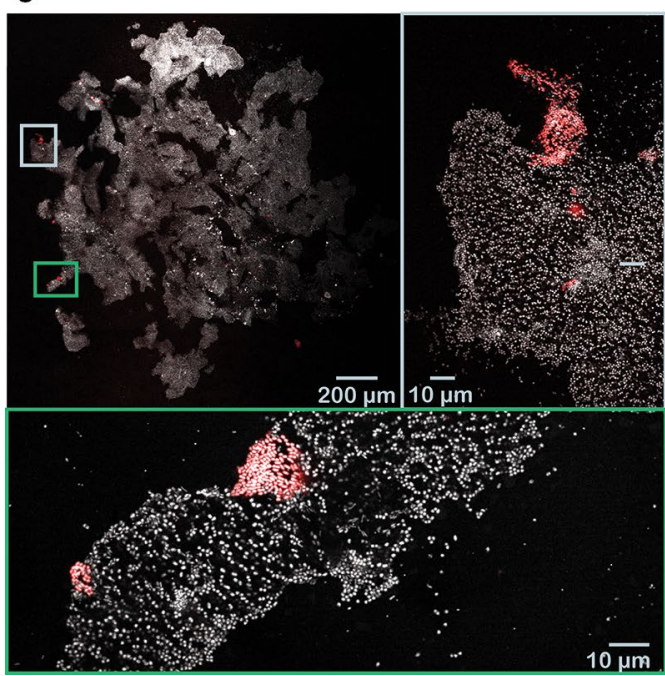

b

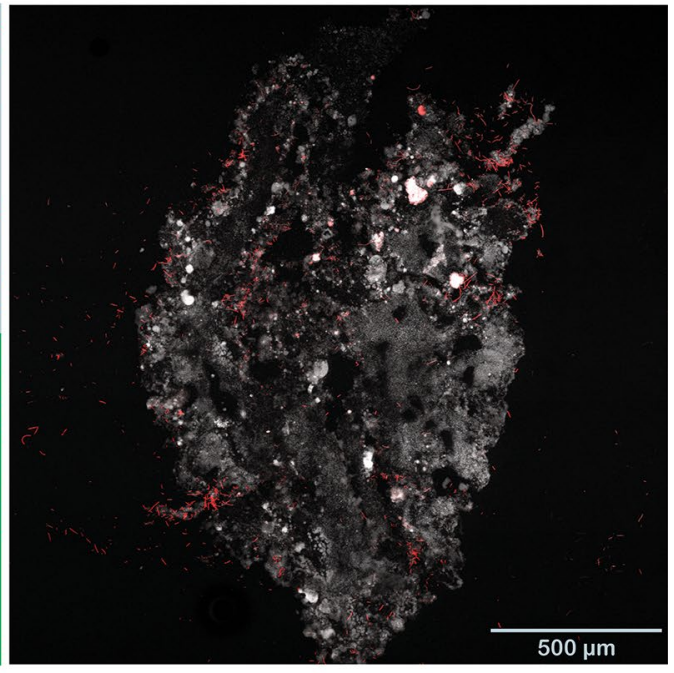

d

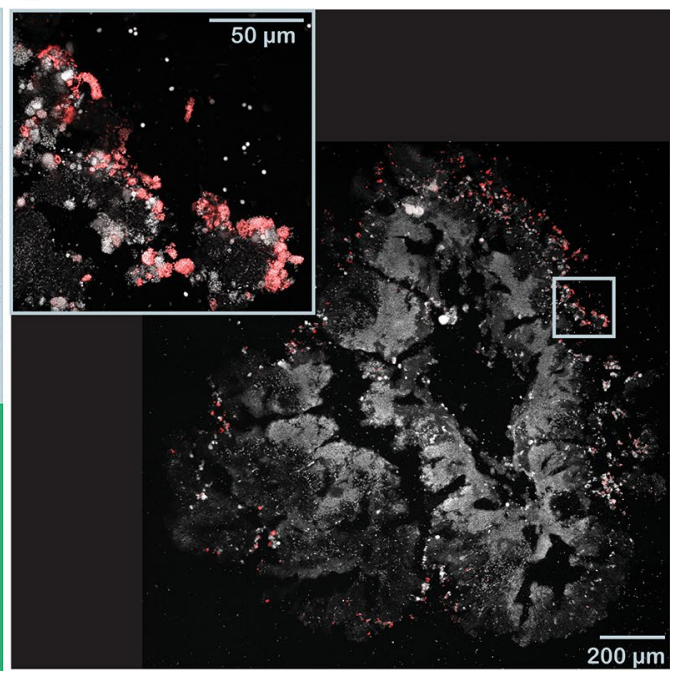

Fig. 4 FISH-CLSM images of selected bacteria with retention ratios significantly lower than one. Cryosections of granules at $\times 200$ magnification and detailed sections at $\times 400$ magnification. a, b Meganema perideroedes in granules from R2; c Zoogloea spp. in granules from R2; d Zoogloea spp. in aerobic granules from R3. Grey total cells (Syto 40); red Meganema perideroedes (a, b) and Zoogloea spp. (c, d)

exposed to high shear force. Another possible explanation for the high abundance in the effluent is that these bacteria grew not only attached to the granule, but also in the bulk liquid as free floating cells. Both Meganema and Zoogloea have high substrate uptake rate and growth rate (Roinestad and Yall 1970; Kragelund et al. 2005), therefore they may also grow in suspended phase even in SBRs operated at 2 min settling time and $9.3 \mathrm{~h}$ HRT. It has also been shown that suspended biomass can be retained under wash-out conditions if attached to the rough surfaces of broken granules (Verawaty et al. 2012) or sheltered in indentations on the granule surface (Gonzalez-Gil and Holliger 2014).
Some genera had a retention ratio significantly larger than one during steady-state operation (Fig. 3). These genera had a higher relative abundance in the granules than in the effluent, and were not washed out of the reactor. However, this does not necessarily mean that their relative abundance in the granules increased with time. For example, Brevundimonas in R1, Acidovorax in R2, or Comamonas in R3 had an average retention ratio above one during steady-state operation (Fig. 3; Table 3), but their relative abundance decreased with time (Additional file 1: Figure S7). In general, no statistically significant correlation was found between the retention ratio and the temporal variation of relative abundance. 
a

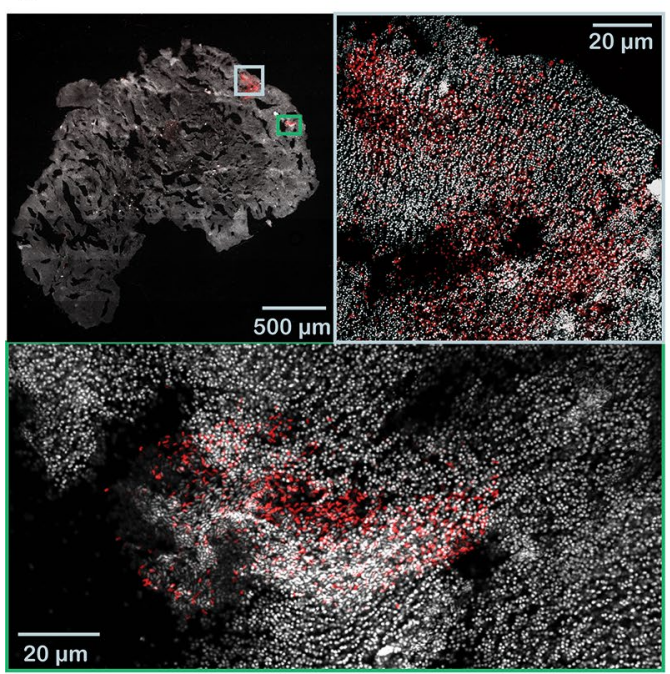

C

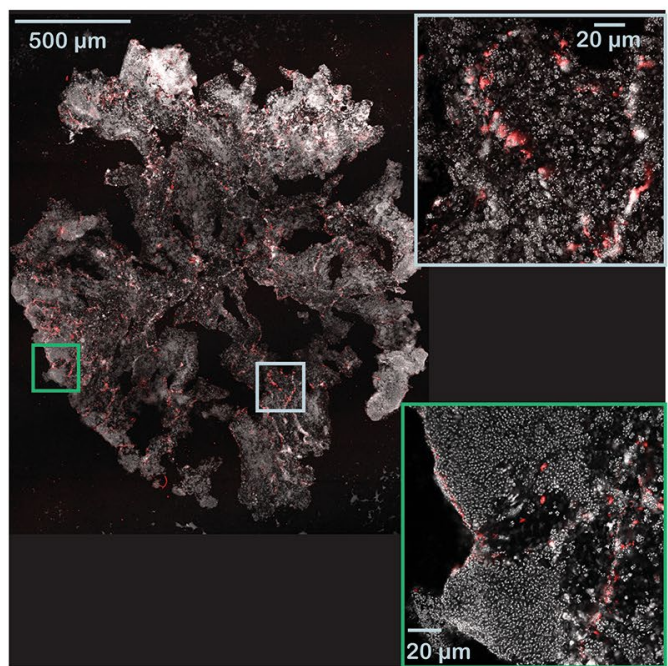

b

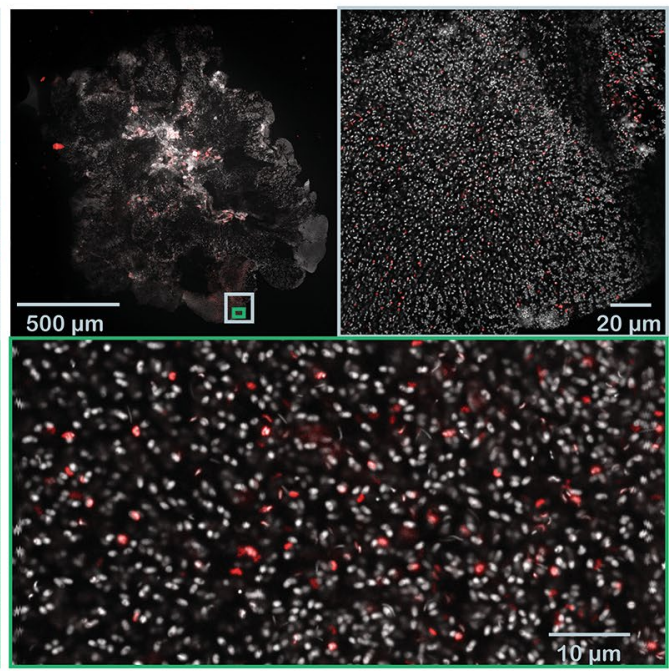

d

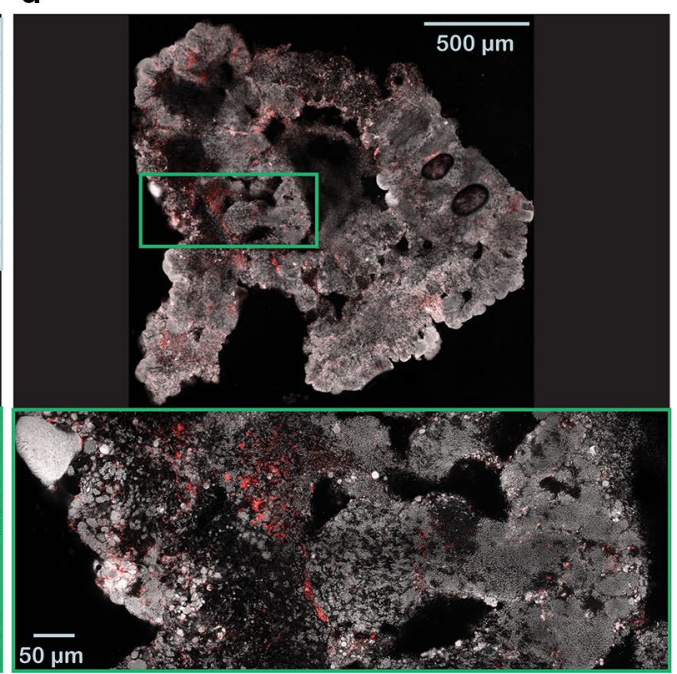

Fig. 5 FISH-CLSM images of selected bacteria with retention ratios significantly higher than one. Cryosections of granules at $\times 200$ magnification and detailed sections at $\times 400$ magnification. $\mathbf{a}, \mathbf{b}$ Genus Bdellovibrio in granules from R1; c, d Flavobacterium spp. in granules from R1. Grey total cells (Syto 40); red genus Bdellovibrio (a, b) and Flavobacterium spp. (c, d)

Slow growing species located in the interior of the granule may be protected from erosion and thus have a high retention ratio $(>1)$, but their relative abundance is likely to decrease because they become outnumbered by other species with higher growth rate. Taxa with consistently high or increasing relative abundance (Additional file 1: Figure S7) and high retention ratio (e.g. Flavobacterium and Bdellovibrio in R1, or OTU_6 in R2 and R3) are presumably growing well under the respective operational conditions, and they are probably growing in the core of the granules (protected from erosion). Indeed, Flavobacterium and Bdellovibrio were located in the inner parts of the granule (Fig. 5), thus suggesting that genera with high retention ratios are actually growing in deeper parts of the granules. Bdellovibrio is a bacterial predator (Rosenberg et al. 2014), while Flavobacterium spp. have been reported to hydrolyze various substrates (Bernardet et al. 1996), thus they are likely to grow on living or dead biomass, soluble microbial products, and EPS. These substrates can be found in the core of the granule. The presence of predatory bacteria like Bdellovibrio has been reported earlier in granular sludge (Wan et al. 2014; Weissbrodt et al. 2014; Li et al. 2014), but the effect of predation on the ecosystem is not yet fully understood. Despite being obligate aerobes (Rosenberg et al. 2014), Bdellovibrio spp. were located in the inner parts of the 
granule. It has been reported earlier that certain Bdellovibrio species can predate under anoxic conditions (Monnappa et al. 2013). Moreover, we have found that oxygen can penetrate the deeper regions of the granules through channels (Szabó et al. 2017), where most of the Bdellovibrio cells were found (Fig. 5).

The core of the granule is not only protected from erosion, but also provides microaerobic and anaerobic niches [above a certain diameter, i.e. after a certain number of weeks of operation, and depending on the bulk COD concentration (Szabó et al. 2017)]. Thus, denitrifying organisms (e.g. Acidovorax spp., Pseudorhodobacter spp., Rhodobacter spp., Fig. 3; Table 3) can be expected to have a high retention ratio (low relative read abundance in the effluent). Bacteria situated in the core are washed out only in case the granule breaks up, and due to the young age ( $<100$ days) of our granules it is likely that very few granules broke up during the experiment (GonzalezGil and Holliger 2014).

EPS producing taxa (e.g. Meganema, Thauera, and Zoogloea) were observed in high abundance in every reactor, which suggests that the predominant aggregation mechanism was microcolony outgrowth (Weissbrodt et al. 2013). These genera are usually present in conventional activated sludge ecosystems, but in lower abundances (in the seed sludge the cumulative relative read abundance of EPS producers was only 13\%). Many of the EPS producing genera typical for sewage treatment plants are mixotrophic bacteria capable of denitrification and/or PHA production (Etchebehere et al. 2003; Lu et al. 2014; Mcllroy et al. 2015; Inoue et al. 2016; Mcllroy et al. 2016). EPS was earlier reported to play an important role in the formation and (mechanical) stability of granular sludge (Weber et al. 2007; Lemaire et al. 2008; Tan et al. 2014), while denitrification was reported to accelerate granule formation (Wan and Sperandio 2009; Suja et al. 2015). The EPS producing functional group was dominated by different genera in the three reactors (Thauera in R1, Meganema in R2 and Zoogloea in R3) due to the different organic loading rates applied.

It can be concluded that the community composition of the suspended phase is similar but not identical to the community composition of the granular phase. Complex patterns were observed for the dynamics of the reactor and effluent microbial communities. During the first part of the experiment, most genera showed similar relative abundance in the reactor and effluent samples. Once granules were developed, bacterial groups located in the interior of the granules tended to be present in lower numbers in the effluent, while taxa growing on the surface and/or in the bulk phase were more abundant in the effluent. However there was no correlation between the degree of wash-out and the temporal dynamics of individual taxa in the granules. Bacteria that were well retained in the granules may be numerically outcompeted over time, as seen by their decreasing relative abundance. On the other hand, bacteria that may appear to be washed out of the system, as seen by their high relative abundance in the suspended phase, may in fact grow in suspension and might even reattach to the granules.

\section{Additional file}

Additional file 1. Additional figures and tables.

\begin{abstract}
Abbreviations
COD: chemical oxygen demand; EPS: extracellular polymeric substance; FISH: fluorescence in situ hybridization; HRT: hydraulic retention time; NMDS: nonmetric multidimensional scaling; OLR: organic loading rate; OUT: operational taxonomic unit; PCR: polymerase chain reaction; SBR: sequencing batch reactor; SS: suspended solids.
\end{abstract}

\section{Authors' contributions}

ES, FP, and B-MW conceived and designed the experiments; ES, RL, and FP contributed to the acquisition of the data; $E S, R L$, and FP contributed to the analysis of the data; $E S, R L, M H, O M, F P$, and B-MW contributed to the interpretation of the data. All authors read and approved the final manuscript.

\section{Author details}

${ }^{1}$ Division of Water Environment Technology, Department of Architecture and Civil Engineering, Chalmers University of Technology, 41296 Gothenburg, Sweden. ${ }^{2}$ Department of Chemistry and Molecular Biology, University of Gothenburg, 40530 Gothenburg, Sweden.

\section{Acknowledgements}

The authors would like to acknowledge Carolina Suarez for her valuable help in FISH analysis and the Centre for Cellular Imaging and the Genomics core facility at the University of Gothenburg for support and use of their equipment.

\section{Competing interests}

The authors declare that they have no competing interests.

\section{Availability of data and materials}

The dataset supporting the conclusions of this article is available in the NCBI Sequence Read Archive repository, BioProject ID: PRJNA384775.

\section{Ethical approval}

This article does not contain any studies with human participants or animals performed by any of the authors.

\section{Funding}

This research was funded by a grant from FORMAS, The Swedish Research Council for Environment, Agricultural Sciences and Spatial Planning (Grant Number 216-2010-1716)

\section{Publisher's Note}

Springer Nature remains neutral with regard to jurisdictional claims in published maps and institutional affiliations.

Received: 30 May 2017 Accepted: 30 August 2017

Published online: 05 September 2017

\section{References}

Albertsen M, Karst SM, Ziegler AS, Kirkegaard RH, Nielsen PH (2015) Back to basics - the influence of dna extraction and primer choice on 
phylogenetic analysis of activated sludge communities. PLoS ONE 10:1-15. doi:10.1371/journal.pone.0132783

Altschul SF, Gish W, Miller W, Myers EW, Lipman DJ (1990) Basic local alignment search tool. J Mol Biol 215:403-410. doi:10.1016/S0022-2836(05)80360-2

APHA (1995) Standard methods for the examination of water and wastewater, 19th edn. American Public Health Association, Washington D.C.

Barr JJ, Cook AE, Bond PL (2010) Granule formation mechanisms within an aerobic wastewater system for phosphorus removal. Appl Environ Microbiol 76:7588-7597. doi:10.1128/AEM.00864-10

Bernardet J-F, Segers P, Vancanneyt M, Berthe F, Kersters K, Vandamme P (1996) Cutting a Gordian Knot: emended classification and description of the genus Flavobacterium, emended description of the family Flavobacteriaceae, and proposal of Flavobacterium hydatis nom. nov. (Basonym, Cytophaga aquatilis Strohl and Tait 1978). Int J Syst Bacteriol 46:128-148. doi:10.1099/00207713-46-1-128

Beun JJ, Hendriks A, van Loosdrecht MCM, Morgenroth E, Wilderer PA, Heijnen $J$ J (1999) Aerobic granulation in a sequencing batch reactor. Water Res 33:2283-2290

Beun JJ, Heijnen JJ, van Loosdrecht MCM (2001) N-removal in a granular sludge sequencing batch airlift reactor. Biotechnol Bioeng 75:82-92. doi:10.1002/bit.1167

de Bruin LMM, de Kreuk MK, van der Roest HFR, Uijterlinde C, van Loosdrecht MCM (2004) Aerobic granular sludge technology: an alternative to activated sludge? Water Sci Technol 49:1-7

de Kreuk MK, Heijnen JJ, van Loosdrecht MCM (2005) Simultaneous COD, nitrogen, and phosphate removal by aerobic granular sludge. Biotechnol Bioeng 90:761-769. doi:10.1002/bit.20470

Derlon N, Wagner J, da Costa RHR, Morgenroth E (2016) Formation of aerobic granules for the treatment of real and low-strength municipal wastewater using a sequencing batch reactor operated at constant volume. Water Res 105:341-350. doi:10.1016/j.watres.2016.09.007

Etchebehere C, Cabezas A, Dabert P, Muxi L (2003) Evolution of the bacterial community during granules formation in denitrifying reactors followed by molecular, culture-independent techniques. Water Sci Technol 48:75-79

Gonzalez-Gil G, Holliger C (2014) Aerobic granules: microbial landscape and architecture, stages, and practical implications. Appl Environ Microbiol 80:3433-3441. doi:10.1128/AEM.00250-14

Inizan M, Freval A, Cigana J, Meinhold J (2005) Aerobic granulation in a sequencing batch reactor (SBR) for industrial wastewater treatment. Water Sci Technol 52:335-343

Inoue D, Suzuki Y, Uchida T, Morohoshi J, Sei K (2016) Polyhydroxyalkanoate production potential of heterotrophic bacteria in activated sludge. $J$ Biosci Bioeng 121:47-51. doi:10.1016/j.jbiosc.2015.04.022

Kozich JJ, Westcott SL, Baxter NT, Highlander SK, Schloss PD (2013) Development of a dual-index sequencing strategy and curation pipeline for analyzing amplicon sequence data on the miseq illumina sequencing platform. Appl Environ Microbiol 79:5112-5120. doi:10.1128/AEM.01043-13

Kragelund C, Nielsen JL, Thomsen TR, Nielsen PH (2005) Ecophysiology of the filamentous Alphaproteobacterium Meganema perideroedes in activated sludge. FEMS Microbiol Ecol 54:111-122. doi:10.1016/j. femsec.2005.03.002

Lemaire R, Webb Rl, Yuan Z (2008) Micro-scale observations of the structure of aerobic microbial granules used for the treatment of nutrient-rich industrial wastewater. ISME J 2:528-541. doi:10.1038/ismej.2008.12

Li Y-M, Zou J, Zhang L, Sun J (2014) Aerobic granular sludge for simultaneous accumulation of mineral phosphorus and removal of nitrogen via nitrite in wastewater. Bioresour Technol 154:178-184. doi:10.1016/j. biortech.2013.12.033

Loy A, Schulz C, Lucker S, Schopfer-Wendels A, Stoecker K, Baranyi C, Lehner A, Wagner M (2005) 165 rRNA gene-based oligonucleotide microarray for environmental monitoring of the betaproteobacterial order "Rhodocyclales". Appl Environ Microbiol 71:1373-1386. doi:10.1128/ AEM.71.3.1373-1386.2005

Lu H, Chandran K, Stensel D (2014) Microbial ecology of denitrification in biological wastewater treatment. Water Res 64:237-254. doi:10.1016/j. watres.2014.06.042

Mahmoud KK, McNeely D, Elwood C, Koval SF (2007) Design and performance of a 165 rRNA-targeted oligonucleotide probe for detection of members of the genus Bdellovibrio by fluorescence in situ hybridization. Appl Environ Microbiol 73:7488-7493. doi:10.1128/AEM.01112-07
Manz W, Amann R, Ludwig W, Schleifer K-H (1992) Phylogenetic Oligodeoxynucleotide probes for the major subclasses of Proteobacteria: problems and solutions. Syst Appl Microbiol 15:593-600

Mcllroy SJ, Saunders AM, Albertsen M, Nierychlo M, Mcllroy B, Hansen AA, Karst SM, Nielsen JL, Nielsen PH (2015) MiDAS: the field guide to the microbes of activated sludge. Database 2015:bav062. doi:10.1093/ database/bav062

Mcllroy SJ, Starnawska A, Starnawski P, Saunders AM, Nierychlo M, Nielsen PH, Nielsen JL (2016) Identification of active denitrifiers in full-scale nutrient removal wastewater treatment systems. Environ Microbiol 18:50-64. doi:10.1111/1462-2920.12614

Monnappa AK, Dwidar M, Mitchell RJ (2013) Application of bacterial predation to mitigate recombinant bacterial populations and their DNA. Soil Biol Biochem 57:427-435. doi:10.1016/j.soilbio.2012.09.010

Morales N, Figueroa M, Fra-Vázquez A, Val del Río Á, Campos JL, Mosquera-Corral A, Méndez R (2013) Operation of an aerobic granular pilot scale SBR plant to treat swine slurry. Process Biochem 48:1216-1221. doi:10.1016/j. procbio.2013.06.004

Nielsen PH, Mielczarek AT, Kragelund C, Nielsen JL, Saunders AM, Kong Y, Hansen AA, Vollertsen J (2010) A conceptual ecosystem model of microbial communities in enhanced biological phosphorus removal plants. Water Res 44:5070-5088. doi:10.1016/j.watres.2010.07.036

Oksanen J, Blanchet FG, Kindt R, Legendre P, Minchin PR, O'Hara RB, Simpson GL, Solymos P, Stevens MHH, Wagner H (2015) vegan: community ecology package. R package version 2.3-2. http://cran.r-project.org/ package $=$ vegan

Pronk M, de Kreuk MK, de Bruin B, Kamminga P, Kleerebezem R, van Loosdrecht MCM (2015) Full scale performance of the aerobic granular sludge process for sewage treatment. Water Res 84:207-217. doi:10.1016/j. watres.2015.07.011

R Core Team (2016) R: a language and environment for statistical computing. R Foundation for Statistical Computing, Vienna. http://www.R-project.org/

Rocktäschel T, Klarmann C, Ochoa J, Boisson P, Sørensen K, Horn H (2015) Influence of the granulation grade on the concentration of suspended solids in the effluent of a pilot scale sequencing batch reactor operated with aerobic granular sludge. Sep Purif Technol 142:234-241. doi:10.1016/j. seppur.2015.01.013

Roinestad FA, Yall I (1970) Volutin granules in Zoogloea ramigera. Appl Microbiol 19:973-979

Rosenberg E, DeLong EF, Lory S, Stackebrandt E, Thompson F (eds) (2014) The prokaryotes. Springer, Berlin

Rosselló-Mora RA, Wagner M, Amann R, Schleifer K-H (1995) The abundance of Zoogloea ramigera in sewage treatment plants. Appl Environ Microbiol 61:702-707

Suja E, Nancharaiah YV, Krishna Mohan TV, Venugopalan VP (2015) Denitrification accelerates granular sludge formation in sequencing batch reactors. Bioresour Technol 196:28-34. doi:10.1016/j.biortech.2015.07.045

Szabó E, Hermansson M, Modin O, Persson F, Wilén B-M (2016) Effects of washout dynamics on nitrifying bacteria in aerobic granular sludge during start-up at gradually decreased settling time. Water 8:172. doi:10.3390/ W8050172

Szabó E, Liébana R, Hermansson M, Modin O, Persson F, Wilén B-M (2017) Microbial population dynamics and ecosystem functions of anoxic/ aerobic granular sludge in sequencing batch reactors operated at different organic loading rates. Front Microbiol 8:770. doi:10.3389/ fmicb.2017.00770

Tan CH, Koh KS, Xie C, Tay M, Zhou Y, Williams R, Ng WJ, Rice SA, Kjelleberg $S$ (2014) The role of quorum sensing signalling in EPS production and the assembly of a sludge community into aerobic granules. ISME J 8:1186-1197. doi:10.1038/ismej.2013.240

Thomsen TR, Blackall LL, Aquino de Muro M, Nielsen JL, Nielsen PH (2006) Meganema perideroedes gen. nov., sp. nov., a filamentous al phaproteobacterium from activated sludge. Int J Syst Evol Microbiol 56:1865-1868. doi:10.1099/ijs.0.02916-0

Thomsen TR, Kong Y, Nielsen PH (2007) Ecophysiology of abundant denitrifying bacteria in activated sludge. FEMS Microbiol Ecol 60:370-382. doi:10.1111/j.1574-6941.2007.00309.x

Verawaty M, Pijuan M, Yuan Z, Bond PL (2012) Determining the mechanisms for aerobic granulation from mixed seed of floccular and crushed granules in activated sludge wastewater treatment. Water Res 46:761-771. doi:10.1016/j.watres.2011.11.054 
Wan J, Sperandio M (2009) Possible role of denitrification on aerobic granular sludge formation in sequencing batch reactor. Chemosphere 75:220227. doi:10.1016/j.chemosphere.2008.11.069

Wan C, Yang X, Lee D-J, Liu X, Sun S (2014) Partial nitrification using aerobic granule continuous-flow reactor: operations and microbial community. J Taiwan Inst Chem Eng 45:2681-2687. doi:10.1016/j.jtice.2014.08.009

Weber SD, Ludwig W, Schleifer K-H, Fried J (2007) Microbial composition and structure of aerobic granular sewage biofilms. Appl Environ Microbiol 73:6233-6240. doi:10.1128/AEM.01002-07

Weissbrodt DG, Neu TR, Kuhlicke U, Rappaz Y, Holliger C (2013) Assessment of bacterial and structural dynamics in aerobic granular biofilms. Front Microbiol 4:175. doi:10.3389/fmicb.2013.00175

Weissbrodt DG, Shani N, Holliger C (2014) Linking bacterial population dynamics and nutrient removal in the granular sludge biofilm ecosystem engineered for wastewater treatment. FEMS Microbiol Ecol 88:579-595. doi:10.1111/1574-6941.12326
Weller R, Glöckner FO, Amann R (2000) 16S rRNA-targeted oligonucleotide probes for the in situ detection of members of the phylum CytophagaFlavobacterium-Bacteroides. Syst Appl Microbiol 23:107-114. doi:10.1016/ S0723-2020(00)80051-X

Winkler MKH, Kleerebezem R, Khunjar WO, de Bruin B, van Loosdrecht MCM (2012) Evaluating the solid retention time of bacteria in flocculent and granular sludge. Water Res 46:4973-4980. doi:10.1016/j. watres.2012.06.027

Yilmaz G, Lemaire R, Keller J, Yuan Z (2008) Simultaneous nitrification, denitrification, and phosphorus removal from nutrient-rich industrial wastewater using granular sludge. Biotechnol Bioeng 100:529-541. doi:10.1002/ bit.21774

Zhou D, Niu S, Xiong Y, Yang Y, Dong S (2014) Microbial selection pressure is not a prerequisite for granulation: dynamic granulation and microbial community study in a complete mixing bioreactor. Bioresour Technol 161:102-108. doi:10.1016/j.biortech.2014.03.001

\section{Submit your manuscript to a SpringerOpen ${ }^{\circ}$ journal and benefit from:}

- Convenient online submission

- Rigorous peer review

- Open access: articles freely available online

- High visibility within the field

- Retaining the copyright to your article

Submit your next manuscript at $\gg$ springeropen.com 